\author{
Меліх 0.0. \\ кандидат економічних наук, доцент \\ E-mail: kafedraekon_01@ukr.net \\ Пасменко Н.B. \\ магістрант \\ кафредра економіки промисловості \\ Одеська національна академія харчових технологій \\ вул. Канатна, 112, м. Одеса, Україна, 65039 \\ E-mail: pasmenkonata1993@mail.ru
}

\title{
СУЧАСНИЙ СТАН ТА НАПРЯМИ РОЗВИТКУ РИНКУ СОНЯШНИКОВОї ОЛІЇ В УКРАÏНІ
}

У статті розглянуто стан та перспективи розвитку ринку соняшникової олії в Україні. Визначено основні чинники, проблеми формування даної галузі, які перешкоджають її успішному розвитку, та запропоновано заходи для підвищення ефективності фрункціонування ринку соняшникової олії і розширення можливостей її реалізації.

Ключові слова: олійні культури, насіння соняшнику, соняшникова олія, попит і пропозиція, ринок, інновації.

Постановка проблеми та їі зв'язок з важливими науковими та практичними завданнями. Виробництво рослинної олії є однією 3 найбільших галузей народного господарства України. Підприємства з виробництва рослинної олії стратегічно важливі для національного господарства як країни в цілому, так і окремих регіонів. Такі підприємства входять у першу п’ятірку галузей харчової промисловості за обсягами виробництва та становлять важливу переробну ланку. На сьогоднішній день вони належать до категорії тих, що позитивно розвиваються. Рослинна олія займає важливе місце в харчуванні людини і є одним 3 основних джерел забезпечення споживчого ринку продовольством. Адже Україна посідає одне з провідних місць серед соняшникосіючих держав та є однією з країн-лідерів 3 переробки та експорту соняшникової олії. За даними Держкомстату останніми роками в Україні виробляється 6,52 млн. тонн соняшнику. Частка ринку в обсязі реалізації продукції харчової промисловості та перероблення сільськогосподарських продуктів досягає $15 \%$.

Аналіз останніх публікацій 3 проблеми. Проблеми розвитку виробництва і реалізації соняшникової олії в Українї розглядали такі вчені, як Бабенко Л.В., Бронін О.В., Домашенко Ю.В., Карман С.В., Карпенко А.В., Митченок О.О., Нікітчин Д.І., Осадчук B.I., Петров В.М., Пластун С.I., Побережна А.А., Присяжнюк С.В., Сегеда С.А., Супіханов Г.Б. та інші. Однак аналіз стану та розвитку олійнопереробної га- лузі на сучасному етапі розвитку економіки вимагає додаткового висвітлення

Формулювання цілей дослідження. Метою статті є дослідження положень щодо вирішення комплексу проблем з підвищення ефективності і стабілізації економіки виробників сировини і переробних підприємств соняшникопереробної промисловості, а також обгрунтування теоретико-методичних засад та розробка практичних пропозицій щодо вдосконалення державного регулювання розвитку цієї галузі народного господарства та формування ринків ії збуту.

Виклад основних результатів та їх обгрунтування. Основною олійною культурою, що вирощується в Україні, є соняшник, у складі всіх олійних культур він займає 70\% посівної площі та 85\% валового збору. У нашій державі з насіння соняшнику виробляється приблизно дві третини всієї рослинної олії. Соняшникова олія має важливе народногосподарське значення. Ї̈і споживають як цінний харчовий продукт у натуральному вигляді, широко використовують у харчовій, лакофарбовій, парфумерній та інших галузях промисловості для виробництва маргарину, оліфи, мила тощо.

Тому соняшник - одна $з$ прибуткових культур України з найвищим рівнем рентабельності серед сільськогосподарських культур. Соняшник більш ніж на $90 \%$ забезпечує сировинну базу і функціонування олійно-жирового підкомплексу України. Так, у 2015 році від реалізації соняшникової олії господарства суспільного сектору отримали 28148,1 млн. грн. прибутку, тому соняшник посідає особливе місце в еко- 
номіці та формуванні експортного потенціалу країни. Високий рівень рентабельності вирощування цієї культури та виробництва 3 неї олії, зумовлений мінімальними виробничими витратами і порівняно високою реалізаційною ціною, стимулював значне розширення посівних площ. Висока відпускна ціна робить олійнопереробну галузь економічно вигідною для народного господарства України, сприяє підйому економіки. Попит на соняшник і соняшникову олію суттєво не зменшується при зростанні цін. Тому виробництво олійних культур і олієжирової продукції $\epsilon$ одним з пріоритетних і перспективних напрямів розвитку аграрного сектора економіки України. За даними Державної служби статистики України посівні площі соняшнику у 2014 році у всіх категоріях господарств становлять 5149,2 тис. га і збільшилися проти 2013 року на 398,3 тис. га.

Найбільше збільшили посівні площі проти минулого року господарства Миколаївської (62,7 тис. га), Дніпропетровської (55,4 тис. га), Херсонської (38,8 тис. га), Запорізької (37,1 тис. га), Полтавської (33,4 тис. га), Кіровоградської (32,7 тис. га) та ряду інших областей.

Збільшення посівних площ викликано високим рівнем прибутковості виробництва соняшнику та значним попитом у світі на рослинні жири. Динаміка виробництва соняшнику в Україні наведена у таблиці 1.

Таблиця 1

Динаміка виробництва соняшнику в Україні

\begin{tabular}{|c|c|c|c|}
\hline Роки & 2011 & 2012 & 2013 \\
\hline Площа, тис. га & 4716,5 & 5081,7 & 5090,1 \\
\hline Валовий збір, тис. тонн & 8670,5 & 8387,1 & 11050,5 \\
\hline Урожайність, ц/га & 18,4 & 16,5 & 21,7 \\
\hline
\end{tabular}

3 таблиці 1 бачимо, що за останні роки спостерігається стабільне зростання посівних площ та урожайності насіння соняшнику, лише у 2012 році був невеликий спад.

Рівень рентабельності виробництва соняшнику у 2011 р. становив 57\%, у 2012 р. - 46\%, у 2013 p. - 21\%. Закупівельна ціна у 2011 р. становила 3225 грн./т, у 2012 р. - 3591 грн./т, у 2013 р. - 3315 грн./т (станом на 14 серпня 2014 р. закупівельна ціна соняшнику без ПДВ становить 4141 грн./т).

Так, висока ціна реалізації соняшникової олії призводить до того, що в окремих регіонах України ця культура в структурі посівних площ займає до $35 \%$, нехтуючи загальним станом грунтів.

Крім того, у порушення всіх агротехнічних вимог, окремі сільгоспвиробники допускають вирощування соняшнику по кілька років на одних і тих же земельних ділянках, хоча припустима періодичність вирощування соняшника - не менше, ніж раз на сім років.

Тривала відсутність спеціальних нормативних актів про відповідальність за безгосподарське та нераціональне використання земель дозволяла як землевласникам, так і землекористувачам споживацьки ставитися до основного національного багатства країни. Вирощування сільськогосподарських культур стало здійснюватись виключно за кон'юнктурою ринку, яка, ігноруючи екологічні вимоги, диктує виробництво, насамперед, «прибуткових культур».
Практика показує, що господарювання в такий спосіб призводить не лише до надмірного виснаження, втрати родючості та погіршення інших корисних властивостей грунтів, а й робить результати діяльності сільськогосподарських підприємств економічно малоефективними, або ж, навіть, збитковими.

На даний час ухвалено проект Закону України «Про збереження грунтів та охорону їх родючості», який виділить грунти та їх родючість як окремий об'єкт правової охорони в державі. За таких умов цей Закон визначатиме особливий статус грунтового покриву у суспільстві і природі, формуватиме дбайливе ставлення всіх верств населення до грунту, унеможливлюватиме процеси його збіднення та деградації.

Також підготовлено проект Закону України «Про внесення змін до деяких законодавчих актів України щодо використання земель сільськогосподарського призначення для ведення товарного сільськогосподарського виробництва», що дасть можливість товаровиробникам розробляти відповідні сівозміни із визначенням основної культури у сівозміні в залежності від напрямку сільгоспвиробництва, без додаткових фінансових затрат та забезпечить дотримання обгрунтованих сівозмін при використанні земель. 
Дані про виробництво соняшникової олії роки наведено у таблиці 2. промисловими підприємствами України за 2011-2013

Таблиця 2

Виробництво соняшникової олії в Україні

\begin{tabular}{|l|c|c|c|}
\hline \multicolumn{1}{|c|}{ Роки } & 2011 рік & 2012 рік & 2013 рік \\
\hline $\begin{array}{l}\text { Олія соняшникова нерафінована та їі фракції, крім фракцій зі } \\
\text { зміненим хімічним складом, тис. т }\end{array}$ & 3177 & 3804 & 3403 \\
\hline
\end{tabular}

3 таблиці 2 видно, що у 2013 році був спад виробництва соняшникової олії у порівнянні з показником попереднього 2012 року на 401 тис. т, але у порівнянні з 2011 роком виробництво збільшилось на 226 тис. т. Це повязано, головним чином, з виробництвом сировини олійнопереробної галузі - соняшнику, яка мала таку ж тенденцію у період 2011-2013 рр. (див. табл. 1).
Обсяг виробництва нерафінованої соняшникової олії в Україні за 10 місяців 2014 року становив 3,4 млн тонн, що на $35,7 \%$ більше, ніж у січні-жовтні 2013 року, повідомляє Державна служба статистики України.

Дані про виробництво соняшникової олії по місяцях 2015 року наведено у табл. 3 .

Виробництво соняшникової олії по місяцях 2015 року

Таблиця 3

\begin{tabular}{|l|c|c|c|c|}
\hline \multicolumn{1}{|c|}{2015 рік } & Січень & Лютий & Березень & Квітень \\
\hline $\begin{array}{l}\text { Олія соняшникова нерафінована та їі фракції } \\
\text { (крім хімічно модифікованих), тис.т }\end{array}$ & 333 & 315 & 341 & 298 \\
\hline
\end{tabular}

Більш наочно динаміку зміни виробництва

соняшникової олії по місяцях за 2015 рік можна побачити на рис. 1.

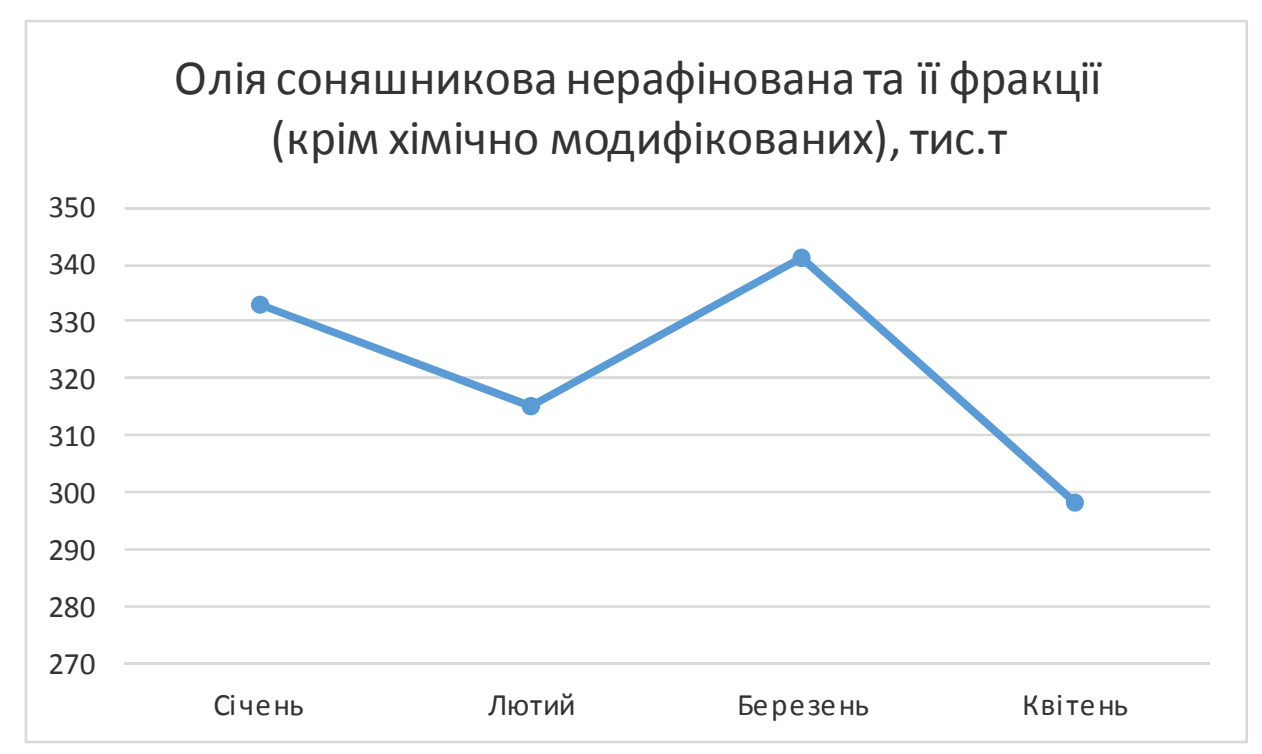

Рис. 1. Динаміка зміни виробництва соняшникової олії за 2015 рік

Виробництво нерафінованої соняшникової олії в Україні у січні 2015 року становило 333 тис. тонн, що на $8,8 \%$ менше, ніж у січні минулого року, повідомила Державна служба статистики України. При цьому січневий показник виробництва соняшникової олії поступається грудневому на 13,6\%. Так, у квітні 2015 року ми спостерігаємо різкий спад виробництва соняшникової олії в порівнянні із почат- ком року, у квітні він становив 298 тис. т. Зниження цього показника, але не на багато, ми бачимо і у лютому - 315 тис. т. Найбільший результат спостеріався у березні 2015, він становив 341 тис. т.

Обсяг реалізованої соняшникової олії за видами діяльності за січень-квітень 2015 року наведено у табл. 4. 
Обсяг реалізованої соняшникової олії за видами діяльності за січень-квітень 2015 року

\begin{tabular}{|l|c|c|c|c|c|}
\hline \multirow{2}{*}{ Назва } & \multirow{2}{*}{ Код КВЕД } & \multicolumn{2}{|c|}{$\begin{array}{c}\text { Обсяг реалізованої промислової } \\
\text { продукції }\end{array}$} & $\begin{array}{c}\text { 3 нього обсяг продукції, реалізо- } \\
\text { ваної за межі України }\end{array}$ \\
\cline { 3 - 6 } & млн. грн & $\begin{array}{c}\text { у \% до всієї реалізо- } \\
\text { ваної продукції }\end{array}$ & млн. грн & $\begin{array}{c}\text { у \% до обсягу РП за } \\
\text { видом діяльності }\end{array}$ \\
\hline $\begin{array}{l}\text { Виробництво олії } \\
\text { та тваринних жи- } \\
\text { рів }\end{array}$ & 10.4 & 28148,1 & 6,0 & 13098,3 & 46,5 \\
\hline $\begin{array}{l}\text { Виробництво олії } \\
\text { та тваринних жи- } \\
\text { рів }\end{array}$ & 10.41 & 26645,0 & 5,7 & 12976,3 & 48,7 \\
\hline
\end{tabular}

3 таблиці 4 видно, що обсяг реалізованої продукції за січень-квітень 2015 року становив 28148,1 млн. грн, у тому числі за межі України 13098,3 млн.грн. Це говорить про те, що 46,5\% продукції іде на експорт, а 53,50\% задовольняє внутрішні потреби населення України.

На сьогоднішній день у нашій державі спостерігається спад виробництва ринку соняшникових культур та продуктів їх переробки (олії), що обумовлено, головним чином, загостренням економічної кризи та нестабільною політичною ситуацією, що склалася в Україні. Негативно також вплинула втрата посівних площ тимчасово окупованих територій. Не зважаючи на це, є тенденція збільшення споживання соняшникової олії для харчування населення, навіть за умови зростання вартості майже на $50 \%$ порівняно з попереднім 2014 роком.

Мінагрополітики України вбачає, що покращення фінансово-економічних показників сільгосптоваровиробників за рахунок соняшнику повинно здійснюватись не за рахунок збільшення його посівних площ, а шляхом впровадження нових технологій, високоврожайних гібридів, дотримання всіх технологічних вимог, що повинно забезпечити належний валовий збір та урожайність.

Розглянувши низку проблем даної галузі України можна говорити про те, що олійно-жирова галузь практично не забезпечується новою технікою, а отже, актуальною є проблема іiі інноваційного розвитку. В Україні існує ряд причин, які перешкоджають останньому: 3 одного боку, відсутність необхідних ресурсів, як на державному, так і на галузевому рівнях, брак обігових коштів у підприємств, а з іншого - в країні досі не задіяні механізми підтримки інноваційної діяльності, ефективність яких підтверджена досвідом багатьох країн світу.

Чимало сучасних проблем олійно-жирового підкомплексу криються у кризі на продовольчому ринку, тому для захисту вітчизняних товаровиробників і споживачів продовольства держава має визначати економічно доцільні параметри експорту продукції олійно-продуктового підкомплексу, виходячи 3 його потенціалу та необхідності задоволення потреб українського ринку.

Висновки та перспективи подальших досліджень. Зважаючи на всі вищеперераховані умови, що характеризують стан ринку соняшникової олії України, автори прийшли до висновку, що слід провести ряд напрямків реформування в галузі. За останні роки в Україні вже напрацьовано певний досвід діяльності господарських структур, створення яких спрямовувалось на активізацію підприємництва. Так, має продовжуватися робота, спрямована на розвиток підприємств і організацій усіх форм власності, підтримку бізнесу, що дозволить підтримувати на високому рівні вітчизняне виробництво соняшникової олії.

Через те, що олійно-жирова промисловість має стратегічне значення для продовольчої безпеки України, державний контроль та регулювання іiі діяльності має бути обов язковим. Саме державне регулювання може відродити олійно-жирову галузь чи загальмувати її розвиток.

Таким чином, пріоритетними напрямами подальшого реформування ринку олійної продукції є: розвиток сільськогосподарської кооперації, реалізація цінової політики шляхом поєднання вільного ціноутворення з елементами державного регулювання; розширення зовнішніх ринків збуту через підвищення конкурентоспроможності насіння соняшнику та вітчизняних продуктів його переробки і оперативне формування відповідної митної політики в залежності від кон'юнктури світового ринку.

Також слід приділити не абияку увагу науково-технічному забезпеченню та науковому супроводженню діяльності цієї галузі господарства. Пріоритетними напрямами буде наукове обгрунтування обсягів сировинної бази та раціонального виробництва i технології переробки соняшникових культур. При цьому великою проблемою $\epsilon$ фінансування досліджень, адже вони мають першочергове значення для виробництва і забезпечення населення даною проду- 
кцією та, в свою чергу, гарантують продовольчу без- пеку.

\title{
Література
}

1. Кириченко В. В. Виробництво соняшникової олії в Укрїні: стан і перспективи розвитку / В. В. Кириченко // Вісник ЦНЗ АПВ - 2014. - № 7. - С. 281-286.

2. Маслак О. М. Сучасні тенденції розвитку ринку соняшникової олії в Україні / О. М. Маслак // Техніка та технологія АПК - 2013. - № 5(8). - С. 35-38.

3. Лисогор В. М. Неформалізований аналіз інноваційних механізмів державного регулювання виробництва соняшникової олії в Україні / В. М. Лисогор // Вісник Хмельницького національного університету. - 2012. - №1. - С. 138-142.

4. Осташко Т. Ризики для сільського господарства від встановлення зони вільної торгівлі з СС / Т. Осташко // Економіка України. - 2011. - № 3. - С. 57-69.

5. Осташко Т. Оцінка ефективності державного регулювання експорту та експортних цін на ринку зернових та олійних культур в Україні / Т. Осташко, Н. Сеперович, О. Протченко, В. Колісник. [Електронний pecypc]. - Режим доступу : http:// www.amdi.org.ua.

6. Прогноз розвитку світового ринку олії на 2014-2016 pр. // Агропрофі, №15 від 14 грудня 2014 року.

7. Офіційний сайт Державного комітету статистики України : http://ukrstat.gov.ua.

8. http://economics.unian.ua/agro/1010940-ukrajina-zbilshila-virobnitstvo-sonyashnikovoji-oliji-na-35.

Стаття надійшла 18.06.2015

\author{
Мелих Е.A. \\ кандидат экономических наук, доцент \\ E-mail: kafedraekon_01@ukr.net \\ Пасменко Н.B. \\ магистрант \\ кафедра экономики промышленности \\ Одесская национальная академия пищевых технологий \\ ул. Канатная, 112, г. Одесса, Украина, 65039 \\ E-mail: pasmenkonata1993@mail.ru
}

\section{СОВРЕМЕННОЕ СОСТОЯНИЕ И НАПРАВЛЕНИЯ РАЗВИТИЯ РЫНКА ПОДСОЛНЕЧНОГО МАСЛА В УКРАИНЕ}

Предприятия по производству растительного масла являются стратегически важными для национального хозяйства как страны в целом, так и отдельных регионов. Такие предприятия входят в первую пятерку отраслей пищевой промышленности по объемам производства. Растительное масло занимает важное место в питании человека и является одним из основных источников обеспечения потребительского рынка продовольствием. Так как масложировая промышленность имеет стратегическое значение для продовольственной безопасности Украины, государственный контроль и регулирование ее деятельности должны быть обязательными. Именно государственное регулирование может возродить масложировую отрасль или затормозить ее развитие.

Таким образом, приоритетными направлениями дальнейшего реформирования рынка масложировой продукции являются: развитие сельскохозяйственной кооперации, реализация ценовой политики путем объединения свободного ценообразования с элементами государственного регулирования; расширение внешних рынков сбыта из-за повышения конкурентоспособности семян подсолнечника и отечественных продуктов его переработки и оперативное формирование соответствующей таможенной политики в зависимости от конъюнктуры мирового рынка.

Ключевые слова: масличные культуры, семена подсолнечника, подсолнечное масло, спрос и предложение, рынок, инновации. 


\author{
Melikh 0.0. \\ Ph.D. in Economics, Associate Professor \\ E-mail: kafedraekon_01@ukr.net \\ Pasmenko N.V. \\ undergraduate \\ Department of Industrial Economics \\ Odessa National Academy of Food Technologies \\ Kanatna str., 112 Odessa, Ukraine, 65039 \\ E-mail: pasmenkonata1993@mail.ru
}

\title{
CURRENT STATUS AND TRENDS OF THE MARKET SUNFLOWER OIL IN UKRAINE
}

Enterprises producing vegetable oil are strategically important for the national economy as a whole as well as individual regions. Such enterprises are in the top five sectors of the food industry in terms of production and processing are an important link. Today, they belong to the category of those that are developing positively. Vegetable oil has an important place in human nutrition and is a major source of food to the consumer market. Because oil and fat industry is of strategic importance for food security of Ukraine, state control and regulation of its activities must be mandatory. It is government regulation can revive oil and fat industry or retard its development.

Thus, the priority areas for further reform of the market of oil products are: development of agricultural cooperation, the implementation of pricing policies by combining free pricing elements of state regulation; expanding foreign markets through improving the competitiveness of domestic sunflower seeds and its products and prompt formation of the relevant customs policy, depending on the world market.

Keywords: oilseed crops, sunflower seeds, sunflower oil, supply and demand, market innovation.

\section{References}

1. Kyrychenko V.V. (2014). Vyrobnytstvo soniashnykovoi olii v Ukrini: stan i perspektyvy rozvytku. Visnyk TsNZ APV, № 7, 281-286.

2. Maslak O.M. (2013). Suchasni tendentsii rozvytku rynku soniashnykovoi olii v Ukraini. Tekhnika ta tekhnolohiia APK , № 5 (8), 35-38.

3. Lysohor V.M. (2012). Neformalizovanyi analiz innovatsiinykh mekhanizmiv derzhavnoho rehuliuvannia vyrobnytstva soniashnykovoi olii v Ukraini. Visnyk Khmelnytskoho natsionalnoho universytetu, № 1, 138-142.

4. Ostashko T. (2011). Ryzyky dlia silskoho hospodarstva vid vstanovlennia zony vilnoi torhivli z YeS. Ekonomika Ukrainy, № 3, 57-69.

5. Ostashko T., Seperovych N., Protchenko O., Kolisnyk V. Otsinka efektyvnosti derzhavnoho rehuliuvannia eksportu ta eksportnykh tsin na rynku zernovykh ta oliinykh kultur v Ukraini [Elektronnyi resurs]. Rezhym dostupu: http:// www.amdi.org.ua.

6. Prohnoz rozvytku svitovoho rynku olii na 2014-2016 rr. (2014). Ahroprofi, №15 vid 14 hrudnia 2014 roku.

7. Ofitsiinyi sait Derzhavnoho komitetu statystyky Ukrainy: http://ukrstat.gov.ua.

8. http://economics.unian.ua/agro/1010940-ukrajina-zbilshila-virobnitstvo-sonyashnikovoji-oliji-na-35. 